\title{
INKONSISTENSI PENEGAKAN HUKUM TINDAK PIDANA HOAKS DI INDONESIA PASCA REFORMASI
}

\author{
Hadi Purnomo, Andre Yosua M \\ Perguruan Tinggi Ilmu Kepolisian (PTIK), Jakarta \\ andreyosuamdosen@gmail.com
}

\begin{abstract}
Abstrak
Artikel ini bertujuan untuk menganalisis bagaimana ketentuan tindak pidana hoaks dalam sistem hukum di Indonesia, dan bagaimana terjadinya inkonsistensi dalam upaya penegakan hukum tindak pidana hoaks di Indonesia. Akhir-akhir ini dunia media sosial terus dibanjiri kritikan terhadap pola penegakan hukum di era presiden Jokowi. Satu tahun pasca menjabat di periode kedua ini perjalanan penegakan hukum dipandang lamban, tebang pilih dan masih terus menuai polemik. Polemik yang menjadi penyebab adalah hukum dijalankan masih dengan cara-cara lama, tebang pilih terhadap pelaku tindak pidana dan penerapan pasal yang terkesan dipaksakan. Salah satu upaya penegakan hukum yang terus menuai kontra adalah penanganan tindak pidana hoaks yang masih tebang pilih. Metode penelitian yang digunakan dalam penelitian ini penelitian hukum normatif. Kesimpulan dari penelitian ini adalah bahwa ketentuan hoaks dalam KUHP dan UU ITE jelas telah tercantum dan secara normatif hoaks tidak sama dengan kritikan. Kritik adalah bagian dari corak kehidupan demokrasi, mematikan demokrasi sama dengan menghilangkan kebiasan kritik. Kendala yang dihadapi dalam upaya penegakan hukum tindak pidana hoaks adalah bahwa unsur politk yang menguasai sistem kenegaraan di Indonesia menyebabkan hukum tidak dapat berjalan secara normal. Unsur kepentingan dan lobi-lobi di elit politik menyebabkan asas legalitas yang didengung-dengunkan negara ini hanya sebuah kehidupan yang formalitas.
\end{abstract}

Kata kunci :Inkonsistensi; Penegakan Hukum; Hoaks. 


\title{
INCONSISTENCY OF LAW ENFORCEMENT OF CRIMINAL ACTS OF HOAX IN INDONESIA POST REFORM
}

\begin{abstract}
This article aims to analyze how the provisions of hoax crime are in the legal system in Indonesia, and how inconsistencies occur in efforts to enforce the hoax crime law in Indonesia. Recently, the world of social media continues to be flooded with criticism of the pattern of law enforcement in the era of President Jokowi. One year after taking office in this second period, the journey of law enforcement is seen as slow, selectively cutting and still reaping polemics. The polemic that is the cause is that the law is still being carried out in the old ways, selective cutting against the perpetrators of criminal acts and the application of articles that appear to be forced. One of the efforts to enforce the law that continues to reap cons is the handling of hoax crimes which are still selectively cut. The research method used in this research is normative legal research. The conclusion of this study is that the hoax provisions in the Criminal Code and the ITE Law are clearly stated and normatively hoax is not the same as criticism. Criticism is part of a democratic life style, killing democracy is tantamount to eliminating the habit of criticism. The obstacle faced in efforts to enforce the law on hoax offenders is that the political elements that control the state system in Indonesia cause the law to not run normally. The elements of interest and lobbying in the political elite cause the legality principle to be echoed by this state only as a form of life. Criticism is part of a democratic life style, killing democracy is tantamount to eliminating the habit of criticism. The obstacle faced in efforts to enforce the law on hoax offenders is that the political elements that control the state system in Indonesia cause the law to not run normally. The elements of interest and lobbying in the political elite cause the legality principle to be echoed by the state as only a form of life. Criticism is part of a democratic life style, killing democracy is tantamount to eliminating the habit of criticism. The obstacle faced in efforts to enforce the law on hoax offenders is that the political elements that control the state system in Indonesia cause the law to not run normally. The elements of interest and lobbying in the political elite cause the legality principle to be echoed by this state only as a form of life.
\end{abstract}

Keywords: Inconsistency; Law Enforcement; Hoax. 


\section{PENDAHULUAN}

\section{A. Latar Belakang}

Hoaks dapat disebut sebagai tindaka criminal di wilayah cyber, dengan kata lain hoaks dapat berupa tindakan kebohongan, manipulasi atau kecurangan yang pata menjatuhkan martabat dan kehormatan orang lain. Menurut Komarudin Hidayat hoaks saat ini sudah sangat berbahaya, peredaran hoaks sudah semakin banyak beredar di media sosial seperti Facebook, Twitter, Instagram, Whatsapp, Telegram dan lain sebagianya. Hoaks yang beredar di masyarakat harus dapat dicegah dan difilter mengingat bahayanya sama dengan maraknya peredaran narkoba. ${ }^{1}$

Pengaturan dan sanksi tentang hoaks sendri sebenarnya telah diatur oleh pemerintah melalui pasal 28 ayat (1) Undang-Undang Nomor 11 Tahun 2008 tentang Informasi dan Transaksi Elektronik (“UU ITE”) sebagaimana yang telah diubah oleh Undang-Undang Nomor 19 Tahun 2016 tentang Perubahan Atas Undang-Undang Nomor 11 Tahun 2008 tentang Informasi dan Transaksi Elektronik ("UU 19/2016”) yang menyatakan: "Setiap Orang dengan sengaja, dan tanpa hak menyebarkan berita bohong dan menyesatkan yang mengakibatkan kerugian konsumen dalam Transaksi Elektronik". Sanksi tentang hoaks ini pun telah diatur dalam pasal 45A ayat (1) UU 19/2016, yaitu: "Setiap Orang yang dengan sengaja dan tanpa hak menyebarkan berita bohong dan menyesatkan yang mengakibatkan kerugian konsumen dalam Transaksi Elektronik sebagaimana dimaksud dalam Pasal 28 ayat (1) dipidana dengan pidana penjara paling lama 6 (enam) tahun dan/atau denda paling banyak Rp 1 miliar”.

Pengaturan selanjutnya tentang hoak juga dapat dilihat dalam pasal 390 Kitab Undang-Undang Hukum Pidana (“KUHP”) juga mengatur hal yang serupa walaupun dengan rumusan yang sedikit berbeda yaitu digunakannya frasa “menyiarkan kabar bohong”, yang berbunyi "Barang siapa dengan maksud hendak menguntungkan diri sendiri atau orang lain dengan melawan hak menurunkan atau

\footnotetext{
${ }^{1}$ https://kominfo.go.id/content/detail/8716/bahaya-hoax-bisa-berujung-pada-pembunuhankarakter/0/sorotan_media', diakses pada tanggal 20 Januari 2021.
} 
menaikkan harga barang dagangan, fonds atau surat berharga uang dengan menyiarkan kabar bohong, dihukum penjara selama-lamanya dua tahun delapan bulan".

Walaupun pengaturan dan sanksi hukum atas penyebaran hoaks telah ada dan adanya tindakan tegas bagi setiap pelaku hoaks, tetapi penyebaran hoaks ditengah masyarakat tetap marak. Dilihat dari sudut pandang psikologis, terdapat dua faktor yang dapat menyebabkan masyarakat dapat mudah percaya pada berita kebohongan tersebut apabila hoaks yang beredar di masyarakat sesuai dengan pendapat atau opini yang dimiliki oleh masyarakat. Penyebab masyarakat percaya terhadap berita hoaks adalah karena terbatasnya pengetahuan atau literasi dari masyarakat itu sendiri. Masyakarat mempunyai keterbatasan dalam menyaring berita bohong yang hadir ditengah-tengah mereka. ${ }^{2}$

Polri maupun Kementerian Komunikasi dan Informasi (Kemenkominfo) dianggap belum siap menghadapi virus hoaks tersebut. Sejauh ini pihak Polri dianggap masih belum adil dalam menangani kasus hoaks yang terjadi di masyarakat, lain halnya ketika terjadi kasus penyebaran ujaran kebencian yang menyangkut kepentingan pemerintah. Harus ada tindakan tegas dari pemerintah dalam hal ini dari Kementerian Kominfo selaku leading sector untuk menutup dan memblokir situs-situs dana kun yang melakukan penyebaran berita hoaks. Sedangkan Polri terkesan hanya terlihat serius mengusut para pelaku yang menjelek-jelekan pemerintah, atau kasus ujaran kebencian yang merugikan kelompok tertentu yang dekat dengan kekuasaan. Sementara kasus ujaran kebencian ataupun tindakan kriminal lainnya yang menimpa kepada ulama dan tokoh partai politik di luar pemerintahan seakan tidak ditangani secara serius.

Telah ada beberapa penelitian sebelumnya yang mengangkat tema tentang penyebaran berita bohong atau hoaks. Penelitian oleh Linda Wati (2020) yang mengangkat penelitian tentang bagaimana ketentuan hukum pidana dan hukum Islam terkait dengan penyebaran berita bohong atau hoaks. Penelitian tersebut

2 Edwi Arief Sosiawan, Rudi Wibowo, "Kontestasi Berita Hoax Pemilu Presiden Tahun 2019 di Media Daring dan Media Sosial”, Jurnal Ilmu Komunikasi 17(2) 2019, hal 133-142. 
menjelaskan bahwa ketentuan pidana penyebaran berita bohong (hoaks) disamping terdapat dalam hukum positif seperti dalam pasal 311 dan pasal 378 KUH Pidana, pasal 45 UU No 19 Tahun 2016 tentang ITE juga telah ada dalam Al Quran yaitu surat An Nur ayat 19. Mengingat penyebaran berita bohong atau hoaks itu sendiri sudah ada sejak jaman Rasulullah Saw. ${ }^{3}$

Penelitian selanjutnya yang terkait dengan penelitian penyebaran berita bohong atau hoaks juga pernah diteliti oleh Hanik Chumairoh (2020). Penelitian tersebut lebih fokus meneliti tentang bagaimana berita bohong atau hoaks yang banyak menyebabkan kontroversi dan membuat kegaduhan di masyarakat khususnya mengenai penyebaran berita bohong di masa pandemi COVID-19 ini. Penelitian ini juga mengkaji bagaimana upaya pemerintah dalam mencegah penyebaran hoaks. Bareskrim Polri melalui unit penanggulangan cyber crime akan memberikan pelayanan dan memberikan rasa aman kepada masyarakat dalam menghadapi kejahatan berita bohong atau hoaks di wilayah cyber. Sedangkan dari kementerian Kominfo sendiri telah memblokir dan menutup akun dan situs -situs yang dianggap telah menyebarkan berita bohong atau hoaks terkait dengan pandemi COVID-19. ${ }^{4}$

Sedangkan penelitian oleh Christiany Juditha (2020) yang berjudul "Perilaku Masyarakat Terkait Penyebaran Hoaks Covid-19" lebih banyak membahas tentang bagaimana perilaku masyarakat menghadapi tersebarnya berita hoaks diseputar penyebaran COVID-19. Penelitian ini lebih sempit yang hanya fokus meneliti perilaku masyarakat dalam menghadapi berita hoaks tentang COVID-19. Adanya penyebaran COVID-19 telah menimbulkan berbagai macam berita hoaks baik yang memuat materi tentang bahaya COVID-19, hoaks tentang COVID-19 maupun segala informasi tentang penyembuhan COVID-19. Masih adanya masyarakat yang turut serta menyebarkan berita hoaks karena beranggapan percaya dan sebagian

\footnotetext{
${ }^{3}$ Linda Wati, "Pidana Penyebaran Berita Bohong (Hoax) Dalam Hukum Pidana Positif (Tinjauan Berdasarkan Hukum Pidana Islam)”, JAL-QANUN: Jurnal Kajian Sosial dan Hukum Islam 1 (1), 2020, hal 77-98. Maret 2020.

${ }^{4}$ Hanik Chumairoh, “Ancaman Berita Bohong di Tengah Pandemi Covid-19”, Jurnal Vox Populi 3 (1), 2020, hal. 22-30. DOI: https://doi.org/10.24252/vp.v3i1.14395
} 
masyarakat ada yang berhenti menyebarkan dan beranggapan itu adalah hoaks semata. Perlu adanya literasi dan penyebaran informasi yang baik dan tepat tentang bagaimana masyarakat dapat menjadi filter adanya berita hoaks. ${ }^{5}$

Penelitian ini berbeda dengan penelitian sebelumnya oleh Linda Wati (2020) yang lebih fokus mengakaji tentang ketentuan pidana dan hukum Islam dalam penyebaran hoaks dan bagaimana ancaman yang dapat terjadi penyebaran hoaks dimasa pandemi COVID-19 yang diteliti oleh Hanik Chumairoh. Sedangakn penelitian oleh Christiany Juditha lebih sempit hanya fokus kepada penelitian tentang perilaku masyarakat terkait dengan penyebaran berita bohong COVID-19. Perbedaan dan kelebihan penelitian ini dibandingkan dengan penelitian sebelumnya adalah penelitian ini ini fokus meneliti tentang inkonsistensi dalam upaya penegakan hukum tindak pidana hoaks di Indonesia, dan masih terjadi tebang pilih dalam penanganan penyebaran berita bohong atau ujaran kebencian. Tujuan dari penelitian ini adalah untuk menganalisis bagaimana ketentuan tindak pidana hoaks dalam sistem hukum di Indonesia, dan bagaimana terjadinya inkonsistensi dalam upaya penegakan hukum tindak pidana hoaks di Indonesia.

\section{B. PerumusanMasalah}

Adapun permasalahan yang diangkat dalam penelitian ini adalah: pertama, Bagaimana Ketentuan Tindak Pidana Hoaks dalam sistem Hukum di Indonesia, kedua, Mengapa terjadi Inkonsistensi dalam Upaya Penegakan Hukum Tindak Pidana Hoaks di Indonesia.

\section{Metode Penelitian}

\section{Jenis Penelitian}

Jenis penelitian yang akan digunakan dalam penelitian ini adalah metode penelitian hukum normatif.

\section{Metode Pendekatan}

Dalam mengkaji permasalahan dalam penelitian ini, maka pendekatan yang digunakan adalah sebagai berikut:

5 Christiany Juditha, "Perilaku Masyarakat Terkait Penyebaran Hoaks Covid-19”, Jurnal Pekommas 5 (2) 2020, hal 105 - 116. DOI: http://dx.doi.org/10.30818/jpkm.2020.2050201 

a. Pendekatan Undang-Undang (Statute Approach)
b. Pendekatan kasus
c. Pendekatan Konseptual (Conceptual Approach)

3.Jenis dan Sumber Bahan Hukum
a. Bahan Hukum Primer
b. Bahan Hukum Sekunder

4. Teknik dan Alat Pengumpulan Bahan Hukum

Bahan hukum yang dikaji dan dianalisis dalam penelitian hukum normatif ini meliputi bahan hukum primer, sekunder, dan tersier.

5. Analisis Bahan Hukum Setelah mengumpulkan bahan hukum dan mengidentifikasinya, maka analisis bahan hukum dilakukan dengan menggunakan metode, yaitu:

a. Penafsiran sistematis tersebut dalam arti jika suatu istilah atau perkataan dicantumkan lebih dari satu kali dalam satu Pasal atau suatu undang-undang, maka pengertiannya harus sama pula.

b. Penafsiran Teologis yaitu mencari tujuan atau maksud dari suatu peraturan perundang-undangan.

\section{PEMBAHASAN}

\section{A. Ketentuan Tindak Pidana Hoaks Dalam Sistem Hukum Di Indonesia}

Dalam Undang-Undang Nomor 11 Tahun 2008 Tentang Informasi dan Transaksi Elektronik tersebut diatur tentang penyebaran berita bohong (hoaks) bagi yang melanggar dapat dikenakan sanksi berikut : Pasal 28 ayat (1) yaitu "muatan berita bohong dan menyesatkan", Pasal 28 ayat (2) yaitu "muatan yang menimbulkan rasa kebencian atau permusuhan individu dan/atau kelompok masyarakat tertentu berdasarkan atas suku, agama, ras, dan antar golongan (SARA)".

Pasal 28 ayat 1 berarti Penyelenggaraan Transaksi Elektronik dapat dilakukan dalam lingkup publik maupun privat. "Penyelenggaraan dalam lingkup publik meliputi suatu penyelenggaraan Transaksi Elektronik oleh Instansi atau pihak oleh pihak lain yang menyelenggarakan layanan publik sepanjang tidak dikecualikan oleh UndangUndang tentang Informasi dan Transaksi Elektronik”. Sedangkan 
penyelenggaraan transaksi elektronik dalam lingkup privat meliputi transaksi elektronik antar pelaku usaha, antar pelaku usaha dengan konsumen, antar pribadi, antar instansi, dan antara instansi dengan pelaku usaha sesuai dengan ketentuan peraturan perundang-undangan.

Dalam teks dari Pasal 28 ayat (1) ini sangat sempit yaitu hanya pada perbuatan penyebaran berita bohong dan penyesatan yang mengakibatkan kerugian konsumen. Dalam hal ini terdapat beberapa celah hukum, diantaranya : "Pertama, pihak yang menjadi korban adalah konsumen dan yang menjadi pelaku adalah perusahaan produsennya. Sementara di lain pihak perlu dipertanyakan apakah produsen juga dapat menjadi korban dari ulah konsumen”. Jika dengan demikian maka terjadi penyebaran berita bohong dan perbuatan tidak menyenangkan lainnya seperti penyesatan yang dilakukan oleh konsumen terhadap produsen melalui berbagai media salah satunya internet, hal tersebut tidak dapat disangkakan dengan pasal ini.

Tidak dapat dihindari bahwa menyebarnya berita hoaks di masyarakat salah satu penyebabnya adalah semakin banyaknya media online yang tidak berafiliasi ke perusahaan pers. Media online tersebut didirikan salah satunyaaalah untuk memenuhi kebutuhan informasi dari suatu komunitas, dan ada juga yang terbit pada masa-masa tertentu tergantung pada situasi politik dan keamanan pada suatu daerah. Biasanya media online seperti ini belum mempunyai badan hukum seperti persyaratan pendirian perusahaan pers sebagaimana yang diamanatkan dalam UU. ${ }^{6}$

Peran pemerintah dalam menangkal berita hoaks pada awalnya memilih dengan memblokir web atau akun yang diduga sebagai sumber penyebaran berita bohong atau ujaran kebencian. Setelah dirasa langkah tersbut kurang efektif dalam menangkal berita bohong dan ujaran kebencian strategi selanjutnya yang dipilih pemerintah adalah dengan membentuk lembaga yang bertugas menagwasi dan

${ }^{6}$ Muh. Arman, M.Syukri Akub,Wiwie Heryani, “Pertanggungjawaban Pidana Pelaku Penyebaran Berita Hoaks Melalui Media Online”, Jurnal Amanna Gappa 26 (1), 2018, hal 1-11. https://doi.org/10.20956/ag.v26i1.6332 
mengelola kegiatan siber di Indonesia. Disamping itu untuk mencegah penyebaran di media sosial dan pers pemerintah melakukan kerjasama dengan Dewan Pers dan Facebook. $^{7}$

Karena bisa jadi antara produsen melakukan manuver untuk saling menjatuhkan perusahaan produsen saingannya dengan menyebarkan berita bohong dan penyesatan terhadap sesama perusahaan produsen, maka dengan teks yang sedemikian perbuatan-perbuatan antar produsen tersebut tidak dapat dijerat oleh pasal ini.

Penyebaran berita bohong dan menyesatkan adalah "suatu berita yang berisi suatu informasi yang tidak benar yang menurut orang-orang pada umumnya dapat membuat pihak konsumen yang melakukan transaksi mengambil keputusan yang seharusnya ia tidak lakukan apabila ia telah mengetahui sebelumnya bahwa informasi tersebut adalah informasi yang tidak benar". ${ }^{8}$ Informasi yang tidak benar yang dimaksudkan ialah suatu informasi mengenai syarat kontrak, produsen, dan produk yang ditawarkan.

"Akibatnya, informasi yang tidak benar itu membuat pihak konsumen mengalami suatu kerugian. Yang dimaksud dengan kerugian ini haruslah kerugian yang ekonomis yang dapat diperhitungkan secara materil dan bukan imateril. Dan pada pasal terkait ketentuan Pasal 28 ayat (2) UU Informasi Transaksi Elektronik masih menimbulkan pemahaman yang multitafsir. Namun pada faktanya, ketentuan dari pasal tersebut telah dipergunakan dalam menyelesaikan banyak kasus yang melanggar isi pasal tersebut".

Pada pelaksanaan penggunaan pasal tersebut di lingkungan peradilan, para penegak hukum terkhusus hakim, harus menggunakan penafsiran hukum untuk memberikan pemahaman bahwa suatu perbuatan telah melanggar pasal tersebut. Penafsiran itu sendiri, menurut D. Simons, "syarat pokok untuk melakukan penafsiran terhadap suatu peraturan perundang-undangan adalah bahwa peraturan

7 Kurniawan Hari Siswoko, "Kebijakan Pemerintah Menangkal Penyebaran Berita Palsu atau Hoax.” Jurnal Muara Ilmu Sosial, Humaniora, Dan Seni, 1(1), 2017, hal 13-19. 10.24912/jmishumsen.v1i1.330

${ }^{8}$ Budi Suhariyanto, (2013), “Tindak Pidana Teknologi Informasi (Cybercrime): Urgensi Pengaturan dan Celah Hukumnya”, Jakarta, Rajawali Pers. H. 92 
tersebut itu harus ditafsirkan berdasarkan peraturan perundang-undangan itu sendiri. Dalam menguraikan penafsiran tersebut, tidak boleh mencari bahan-bahan di luar peraturan tersebut. Pada faktanya, meskipun suatu peraturan perundangundangan itu telah dibentuk dengan mempergunakan kata-kata dan istilah yang tegas, akan tetapi masih ada kemungkinan untuk memberikan penafsiran, bahkan dapat menimbulkan keraguan". 9

Secara khusus, perkembangan teknologi informasi dan komunikasi memberikan implikasi-implikasi yang signifikan terhadap pengaturan atau pembentukan regulasi dalam ruang siber dan hukum siber serta terhadap perkembangan kejahatan dalam dunia maya atau biasa disebut cybercrime. ${ }^{10}$ "Pertanggungjawaban pidana pada dasarnya dapat dipertanggungjawabkan kepada diri seorang pelaku tindak pidana, tetapi harus memenuhi 4 (empat) unsur persyaratan" sebagai berikut: ${ }^{11} 1$. Ada suatu tindakan (commission atau omission) oleh si pelaku; 2. Yang memenuhi rumusan-rumusan delik dalam Undangundang; 3. Tindakan itu bersifat melawan hukum; 4. Pelakunya harus bisa dipertanggungjawabkan.

Terdapat dalam undang-undang Nomor 1 Tahun 1946 Tentang Peraturan Hukum Pidana, yaitu diatur dalam Pasal 14 ayat (1), dan ayat (2), serta Pasal 15 UU No. 1 Th 1946 tentang Peraturan Hukum Pidana. Esensi dari ketentuan Pasal 14 ayat (1) yaitu "akibat dari penyebaran berita bohong menyebabkan terjadinya keresahan di kalangan rakyat, maka akan dihukum penjara paling lama sepuluh tahun penjara". Esensi dari Pasal 14 ayat (2) yaitu "menyebarkan berita yang dapat menimbulkan keresahan di kalangan rakyat, dan pelaku tidak menyadari bahwa berita tersebut adalah bohong maka dihukum paling lama tiga tahun penjara”. Esensi dari Pasal 15 yaitu "menyiarkan berita yang tidak pasti, dan pelaku

9 P.A.F. Lamintang, dan C. Djisman Samosir, 2010, "Delik-delik Khusus Kejahatan yang Ditujukan Terhadap Hak Milik dan lain-lain Hak yang Timbul dari Hak Milik", Bandung, TARSITO Bandung

10 Josua Sitompul, 2012, "Cyberspace, Cybercrimes, Cyberlaw Tinjauan Aspek Hukum Pidana", Tatanusa, Jakarta, hal 26. 67.

${ }^{11}$ Romli Atmasasmita, 2000, "Perbandingan Hukum Pidana”, Penerbit Mandar Maju, Bandung, hal 
menyadari bahwa berita tersebut akan mudah menimbulkan keresahan di kalangan rakyat, maka dihukum paling lama dua tahun penjara".

Ancaman pidana penyebaran berita bohong (hoaks) diatur dalam: Dalam Undang-Undang No 1 Tahun 1946 pada Pasal 14 ayat (1) yaitu: "barangsiapa, dengan menyiarkan berita bohong, dengan sengaja menerbitkan keonaran dikalangan rakyat, dihukum dengan hukuman penjara setinggi-tingginya sepuluh tahun". Ayat (2) "barang siapa meyiarkan suatu berita atau mengeluarkan suatu pemberitahuan yang dapat menerbitkan keonaran dikalangan rakyat, sedangkan ia patut dapat menyangka bahwa berita atau pemberitahuan itu adalah bohong, dihukum dengan penjara setinggi-tingginya adalah tiga tahun.”

Pasal 15 yang berbunyi "barangsiapa menyebarkan kabar yang tidak pasti atau kabar yang berkelebihan yang tidak lengkap, sedangkan ia mengerti setidaktidaknya patut dapat menduga bahwa kabar demikian akan atau sudah dapat menerbitkan keonaran di kalangan rakyat, di hukum dengan hukuman penjara setinggi-tingginya dua tahun". Dalam Kitab Undang-Undang Hukum Pidana (KUHP) Pasal 311 KUHP : “jika yang melakukan kejahatan pencemaran atau pencemaran tertulis dibolehkan untuk membuktikan apa yang dituduhkan itu benar, tidak membuktikannya, dan tuduhan dilakukan bertentangan dengan apa yang diketahui, maka dia diancam melakukan fitnah dengan pidana penjara paling lama empat tahun".

Pasal 378 KUHP berbunyi "barang siapa dengan maksud untuk menguntungkan diri sendiri atau orang lain secara melawan hukum, dengan memakai nama palsu atau martabat palsu, dengan tipu muslihat, atau rangkaian kebohongan, menggerakkan orang lain untuk menyerahkan barang sesuatu kepadanya, atau supaya memberikan hutang maupun menghapuskan piutang diancam karena penipuan dengan pidana penjara paling lama empat tahun". ${ }^{2}$

Dalam Undang-Undang No 19 Tahun 2016 tentang ITE terdapat pada Pasal 45 ayat (2): “setiap orang yang memenuhi unsur sebagaimana dimaksud dalam pasal 28 ayat (1) dan ayat (2) dipidana dengan pidana penjara paling lama 6 (enam)

12 R. Soesilo, 1986, “Kitab Undang-undang Hukum Pidana (KUHP)”, Bogor, Politeia, hal 260-261. 
tahun dan/atau denda paling banyak Rp. 1.000.000.000,00; (satu miliar)". Bahwa penyebaran berita bohong (hoaks) melanggar pasal 28 ayat 1 Undang-Undang Nomor 11 Tahun 2008 Tentang ITE. Tindak pidana pidana penyebaran berita bohong (hoaks) dikenakan sanksi pidana penjara. ${ }^{13}$

Pemidanaan adalah tahap dimana pelaku dikenai sanksi. "Pemidanaan merupakan bentuk hukuman kepada seorang penjahat dan memberikan akibat positif untuk si pelaku, korban, maupun masyarakat". Teori ini kemudian disebut dengan teori konsekuensialisme. Sehingga maksud pidana yang sebenarnya adalah "supaya seseorang tidak melakukan lagi kejahatannya setelah dipidana dan dapat mencegah orang lain untuk melakukan hal yang sama”. Dengan adanya sanksi yang tegas, orang-orang akan memiliki sekurang-kurangnya rasa takut untuk melanggar, sehingga pemidanaan dan/atau denda diperlukan sebagai ancaman sanksi terhadap pelaku tindak pidana. ${ }^{14}$

\section{B. Dampak Inkonsistensi Penegakan Hukum Tindak Pidana Hoaks}

Negara Indonesia yang notabenenya adalah negara hukum, maka segala sesuatu yang berkenaan dengan pelanggaran hukum atau tidak taat pada aturan hukum yang ada akan mendapatkan sanksi yang tegas bagi pelakunya. Dianjurkan bagi siapa saja yang hidup sebagai warga masyarakat yang hidup di bumi pertiwi ini agar dapat menciptakan keteraturan sosial dengan baik yaitu menjunjung tinggi hukum yang berlaku.

Sesuai struktur hukum dalam suatu negara bahwa "hukum yang paling tinggi dalam suatu negara adalah hukum negara dalam hal mana peraturan perundangan atau hukum yang berada dibawahnya harus tunduk dan tidak boleh bertentangan dengan hukum negara". Plato, T. Hobbes dan Hegel, menyatakan "bahwa hukum negara lebih tinggi dari hukum yang lainnya sehingga tidak ada hukum lain yang bertentangan dengan hukum negara". ${ }^{15}$ Hukum yang berkembang dalam

\footnotetext{
13 Ismu Gunadi, Joenaidi Efendi, 2015, “Cepat dan Mudah Memahami Hukum Pidana”, Jakarta: Kencana Prenada Media Group, hal. 68.

14 Yunita Rahayu Kurniawati, "Pertanggungjawaban Pidana Atas Penyebaran Berita Bohong (Hoax) Di Media Sosial”, Dinamika, Jurnal Ilmiah Ilmu Hukum 26 (4), 2020, hal 430.

(2), 2010. Bambang Sutiyoso, “Mencari Format Ideal Keadilan Putusan dalam Peradilan”, .Jurnal Hukum 1
} 
masyarakat, yaitu hukum yang berkenaan dengan maraknya kasus-kasus saat ini sangat mempengaruhi pola pikir dari warga masyarakat. Sebagai contoh hukum yang diterapkan dengan tidak menjunjung asas keadilan dalam masyarakat, yaitu hukum tumpul keatas dan hukum tumpul kebawah. Perlakuan yang berbeda dari penegakan hukum, sehingga terdapat kesan hukum hanya berlaku bagi masyarakat kelas bawah sedangkan hukum bagi penguasa dapat diperjual belikan. Fakta yang sangat ironis sekali, hukum tidak berjalan sebagaimana mestinya.

Sulitnya penegakan hukum di Indonesia berawal sejak peraturan perundangundangan dibuat. Paling tidak ada dua alasan untuk mendukung pernyataan ini. Pertama, "pembuat peraturan perundang-perundangan tidak memberi perhatian yang cukup apakah peratura perundang-undangan sadar ataupun tidak. Pembuat peraturan perandang-undangan sadar atau tidak telah mengambil asumsi aturan yang dibuat akan dengan sendirinya dapat berjalan". Kedua, "peraturan perundangundangan kerap dibuat secara tidak realistis, ini terjadi terhadap pembuatan peraturan perundang-undangan yang merupakan pesanan dari elit politik. Negara asing maupun lembaga keuangan internasional”. Di sini peraturan perundangundangan dianggap sebagai komoditas. Elit politik dapat menentukan agar suatu peraturan perundang-undangan dibuat dapat menentukan agar suatu peraturan perundang-undangan dibuat bukan karena kebutuhan masyarakat, melainkan agar Indonesia mematuhi peraturan perundang-undangan yang sebanding (comparable) dengan negara industri. Sementara negara asing ataupun lembaga keuangan internasional dapat meminta Indonesia dapat pinjaman atau hibah dari luar negeri. ${ }^{16}$

Penyebaran hoaks yang dilakukan melalui media internet juga dapat dijerat pidana, hal ini diatur dalam ketentuan pasal 45A Ayat (1) Undang-Undang Nomor 19 Tahun 2016 Tentang Perubahan Atas Undang-Undang Nomor 11 Tahun 2008 Tentang Informasi dan Transaksi Elektronik Selanjutnya disebut UU ITE yang menyatakan "Setiap Orang yang dengan sengaja dan tanpa hak menyebarkan berita bohong dan menyesatkan yang mengakibatkan kerugian konsumen dalam transaksi

16 Soetandyo Wignjosoebroto. 2008, "Hukum dalam Masyarakat”, Malang, Bayumedia Publishing, hal 63. 
elektronik sebagaimana dimaksud dalam Pasal 28 ayat (1) dipidana dengan pidana penjara paling lama 6 (enam) tahun dan/atau denda paling banyak Rp1.000.000.000,00 (satu miliar rupiah)”. Berdasarkan ketentuan diatas maka penyebar hoaks dapat dipidana jika memenuhi unsur-unsur dengan sengaja dan tanpa hak, menyebarkan berita bohong dan menyesatkan, mengakibatkan kerugian konsumen dalam transaksi elektronik. Frase "menyebarkan berita bohong dan menyesatkan" menciptakan suatu hubungan sebab dan akibat yang menjelaskan sebab "berita bohong" tersebut akibatnya "menyesatkan".

Pemidanaan bagi para pelaku penyebar berita bohong atau hoaks di media sosial tidak hanya dapat dikenakan kepada pembuat atau penulis berita bohong dan penyebar pertama kali saja tetapi juga dapat dikenakan kepada siapapun yang turut serta membagikan/mendistribusikan/share/forward berita bohong tersebut yang ada di media sosial. ${ }^{17}$

Kita tidak dapat menjelaskan tentang efektifitas hukum tanpa membicarakan lebih dahulu tentang hukum dalam tataran normative (law in books) dan hukum dalam tataran realita (law in action), sebab tanpa membandingkan kedua variable ini adalah tidak mungkin untuk mengukur tingkat efektifitas hukum. Donald Black berpendapat bahwa "efektifitas hukum adalah masalah pokok dalam sosiologi hukum yang diperoleh dengan cara memperbandingkan antara realitas hukum dalam teori, dengan realitas hukum dalam praktek sehingga nampak adanya kesenjangan antara keduanya. Hukum dianggap tidak efektif jika terdapat perbedaan antara keduanya". Untuk mencari solusinya, langkah solusinya, langkah apa yang harus dilakukan untuk mendekatkan kenyataan hukum (das sein) dengan ideal hukum (das sollen) agar 2 (dua) variabel (law in books dan law in action) menjadi sama?

Hukum yang efektif adalah hukum yang sesuai dengan peraturan yang telah dibuat dalam undang-undang dan hukum yang sesuai dengan harapan atau cita-cita dari masyarakat. Manakala dengan adanya hukum tersebut akan menjadikan

17 Nur Aisyah Siddiq, "Penegakan Hukum Pidana Dalam Penanggulangan Berita Palsu (Hoax) Menurut Undang-Undang No.11 Tahun 2008 Yang Telah Dirubah Menjadi Undang-Undang No.19 Tahun 2016 Tentang Informasi Dan Transaksi Elektronik”, Jurnal Lex Et Societatis 5 (10) , 2017, hal 30. 
keteraturan sosial dalam masyarakat. Berbicara tentang hukum memang sangat pelik terdapat takaran sebuah kenyataan hukum dan sebuah ideal hukum. Kadangkala apa yang sudah menjadi ketetapan dalam undang-undang sebuah hukum tidak sesuai dengan keinginan masyarakat, ataupun sebaliknya masyarakat menginginkan sebuah hukum yang baru. Perubahan hukum dalam masyarakat dapat saja terjadi karena dirasa memang sangat perlu yaitu dengan hadirnya peraturan atau norma-norma yang sesuai dengan keadaan zaman masa kini.

\section{PENUTUP}

Pengaturan Hoaks sebagai suatu perbuatan pidana di Indonesia telah diatur dalam Undang-Undang No 1 Tentang Peraturan Hukum Pidana dan UndangUndang ITE. Pengaturan Hoaks di dalam pasal 45A UU ITE memiliki tafsir yang kurang spesifik, hal ini dikarenakan tidak dijelaskan lebih lanjut mengenai frase "berita bohong dan menyesatkan", padahal ruang lingkup dari berita bohong jika dilihat dari dampaknya yang menyesatkan sangatlah luas. Ketiadaan definisi dari sejauh apa dampak menyesatkan dapat membuat timbulnya multitafsir sehingga menyebabkan kekaburan norma. Proses penegakan hukum masih jauh dari harapan kita semua, hukum tumpul keatas dan hukum tajam kebawah. Rasa keadilan tidak menyentuh bagi kelas bawah, sedangkan mereka yang memiliki kelas sosial lebih tinggi maka akan dengan mudah mendapatkan perlakuan yang lebih istimewa. Kasus-kasus yang mengemuka terdapat sebuah problematika dalam penegakan hukum. Seolah-olah hukum dapat diperjual belikan. Hukum semestinya dapat berjalan secara efektif apabila semua sadar diri akan pentingnya menjunjung tinggi nilai-nilai hukum yang berada dalam masyarakat.

\section{DAFTAR PUSTAKA}

\section{Buku}

Budi Suhariyanto, (2013), "Tindak Pidana Teknologi Informasi (Cybercrime): Urgensi Pengaturan dan Celah Hukumnya", Jakarta, Rajawali Pers.

Ismu Gunadi, Joenaidi Efendi, "Cepat dan Mudah Memahami Hukum Pidana”, ( Jakarta: Kencana Prenada Media Group, 2015)

Josua Sitompul, 2012, "Cyberspace, Cybercrimes, Cyberlaw Tinjauan Aspek Hukum Pidana”, Tatanusa, Jakarta. 
P.A.F. Lamintang, dan C. Djisman Samosir, (2010), "Delik-delik Khusus Kejahatan yang Ditujukan Terhadap Hak Milik dan lain-lain Hak yang Timbul dari Hak Milik", Bandung: TARSITO Bandung.

R. Soesilo, "Kitab Undang-undang Hukum Pidana (KUHP)”, (Bogor: Politeia, 1986).

, "Kitab Undang-Undang Hukum Pidana (KUHP) Serta KomentarKomentarnya Lengkap Pasal Demi Pasal”, Bogor: Politeia, 1991.

Romli Atmasasmita, 2000, "Perbandingan Hukum Pidana", Penerbit Mandar Maju, Bandung.

Soetandyo Wignjosoebroto. 2008. "Hukum dalam Masyarakat”, Malang : Bayumedia Publishing.

\section{Jurnal}

Bambang Sutiyoso, "Mencari Format Ideal Keadilan Putusan dalam Peradilan”, Jurnal Hukum 2 (1), 2010.

Edwi Arief Sosiawan, Rudi Wibowo, "Kontestasi Berita Hoax Pemilu Presiden Tahun 2019 di Media Daring dan Media Sosial”, Jurnal Ilmu Komunikasi 17(2) 2019.

Christiany Juditha, "Perilaku Masyarakat Terkait Penyebaran Hoaks Covid-19" Jurnal Pekommas 5 (2) 2020.

DOI: http://dx.doi.org/10.30818/jpkm.2020.2050201

Hanik Chumairoh, "Ancaman Berita Bohong di Tengah Pandemi Covid-19", Jurnal Vox Populi 3 (1), 2020, DOI: https://doi.org/10.24252/vp.v3i1.14395

Kurniawan Hari Siswoko, "Kebijakan Pemerintah Menangkal Penyebaran Berita Palsu atau Hoax.” Jurnal Muara Ilmu Sosial, Humaniora, Dan Seni, 1(1), 2017. 10.24912/jmishumsen.v1i1.330

Linda Wati, "Pidana Penyebaran Berita Bohong (Hoax) Dalam Hukum Pidana Positif(Tinjauan Berdasarkan Hukum Pidana Islam)”, JAL-QANUN: Jurnal Kajian Sosial dan Hukum Islam 1 (1), 2020.

Muh. Arman, M.Syukri Akub,Wiwie Heryani, "Pertanggungjawaban Pidana Pelaku Penyebaran Berita Hoaks Melalui Media Online", Jurnal Amanna Gappa 26 (1), 2018. https://doi.org/10.20956/ag.v26i1.6332

Nur Aisyah Siddiq, "Penegakan Hukum Pidana Dalam Penanggulangan Berita Palsu (Hoax) Menurut Undang-Undang No.11 Tahun 2008 Yang Telah Dirubah Menjadi Undang-Undang No.19 Tahun 2016 Tentang Informasi Dan Transaksi Elektronik”, Jurnal Lex Et Societatis 5 (10), 2017.

Yunita Rahayu Kurniawati, "Pertanggungjawaban Pidana Atas Penyebaran Berita Bohong (Hoax) Di Media Sosial”, Dinamika, Jurnal Ilmiah Ilmu Hukum 26 (4), 2020.

\section{Peraturan Perundang-Undangan}

Undang-Undang Nomor 1 Tahun 1946 tentang Peraturan Hukum Pidana

Undang-Undang Nomor 11 Tahun 2008 tentang Informasi dan Transaksi Elektronik 
Inkonsistensi Penegakan Hukum Tindak Pidana Hoaks

Di Indonesia Pasca Reformasi

Hadi Purnomo, Andre Yosua M

p-ISSN : 2541-2345, e-ISSN : 2580-8842

Undang-Undang Nomor 19 Tahun 2016 tentang Perubahan Atas Undang-Undang

Nomor 11 Tahun 2008 Tentang Informasi dan Transaksi Elektronik 